\title{
Simulating Grazing Effects on Soil Organic Carbon Dynamics in Semi-arid Rangelands (Southern Iran)
}

sayed fakhreddin afzali ( $\sim$ afzalif@shirazu.ac.ir)

Shiraz University https://orcid.org/0000-0001-6365-7382

\section{Bijan AZAD}

depatment of Rehabilitation of Arid and Mountainous Regions, Faculty of Natural Resources, University of Tehran, Tehran, Iran.

\section{Rosa FRANCAVIGLIA}

CREA, Council for Agricultural Research and Econimics, Research Centre FOR Agriculture and Environment,00184 Rome, Italy.

\section{Research Article}

Keywords: CENTURY model, SLOC, SOC, grazing intensity, semi-arid rangelands

Posted Date: June 8th, 2021

DOl: https://doi.org/10.21203/rs.3.rs-519337/v1

License: (1) (1) This work is licensed under a Creative Commons Attribution 4.0 International License. Read Full License 


\section{Simulating grazing effects on soil organic carbon dynamics in semi-arid}

\section{2 rangelands (Southern Iran)}

3 RUNNING TITLE: Simulating soil organic carbon

4

5 Sayed Fakhreddin AFZALI ${ }^{1, *}$, Bijan AZAD $^{1,2}$, Rosa FRANCAVIGLIA $^{3}$

$6{ }^{1}$ Department of Natural Resource and Environmental Engineering, School of Agriculture, Shiraz

7 University, Shiraz, Iran, afzalif@shirazu.ac.ir.00989022232772

$8{ }^{2}$ Department of Rehabilitation of Arid and Mountainous Regions, Faculty of Natural Resources,

$9 \quad$ University of Tehran, Tehran 31587-77871, Iran.

$10{ }^{3}$ CREA, Council for Agricultural Research and Economics, Research Centre for Agriculture and

11 Environment, 00184 Rome, Italy

$12 *$ Corresponding author. E-mail: $\underline{\text { afzalif@ shirazu.ac.ir }}$

13

14 Declarations of interest: none 

in semi-arid rangelands (Southern Iran)

21 RUNNING TITLE: Simulating soil organic carbon

22 Abstract

Grazing is one of the main causes of rangeland degradation worldwide, due to the effects of overgrazing on vegetation cover and biodiversity. But few data are available on the effect of grazing intensity on the dynamics of soil organic carbon (SOC) and soil labile organic carbon (SLOC). So far, very few studies have addressed the modeling of SOC dynamics under different grazing intensities, and SLOC dynamics has not been modeled yet. In this study, we used the CENTURY model to select the most effective grazing management in terms of carbon sequestration (SOC and SLOC stocks) in semi-arid rangelands of Southern Iran. The effect of four different scenarios of grazing intensity was simulated: no grazing, light grazing (LG), moderate grazing (MG), and heavy grazing (HG). The results of long-term model simulations (2015-2100), indicated that SOC stocks will change by $2.7,1.7,-23.4$, and $-24.6 \%$ in the scenarios of exclusion, $\mathrm{LG}, \mathrm{MG}$, and HG respectively compared to 2014. With increasing grazing intensities, SLOC stocks in LG, MG, and HG scenarios significantly decreased compared to the no grazing scenario by 26.1, 59.6, and 70\%, respectively. Thus, this study suggests recommending light grazing management for semi-arid rangelands of Iran and also SLOC as a suitable index for studying the effect of grazing on soil carbon.

Key words: CENTURY model; SLOC; SOC; grazing intensity; semi-arid rangelands.

\section{Introduction}

Soils have a prominent role in maintaining the balance of the global carbon cycle (La, 2008), and any small change in soil organic carbon (SOC) has high impacts on the 
concentration of $\mathrm{CO}_{2}$ in the atmosphere (Smith et al., 2008; Muñoz-Rojas et al., 2015). Rangelands have a high potential to sequester the atmospheric $\mathrm{CO}_{2}$ in the soil due to their prevalence in about 50\% of land area worldwide, and globally can store up to $30 \%$ of SOC (Derner and Schuman, 2007). In particular, one of the most effective factors in SOC storage is grazing management (Mcsherry and Ritchie, 2013; Waters et al., 2016). Grazing is one of the main causes of rangeland degradation particularly in arid and semi-arid environments, due to the effects of overgrazing on vegetation cover, biodiversity of plant species, unpalatable species, and livestock trampling that enhance soil loss by erosion, reduce the production potential of rangelands, and negatively affect SOC, SOC pools and soil biological activity (Derner and Schuman, 2007; Cao et al., 2013; Al-Rowaily et al., 2015; Sepe et al., 2015).

Recent research has shown that grazing intensity affects SOC stocks, net primary production, root growth, plant shoot/root allocation, soil $\mathrm{C} / \mathrm{N}$ ratio, and organic matter decomposition (Derner et al., 2006; Derner and Schuman, 2007; Pineiro et al., 2010; Ritchie, 2014; Papanastasis et al., 2015; Orgill et al., 2016). Furthermore, other studies have shown that short-term periods are not adequate for the evaluation of grazing effects on SOC stocks, so long-term investigations have been recommended (Medina-Roldán et al., 2012).

To investigate the effects of grazing on soil carbon, two pools of soil decomposable carbon including soil labile organic carbon (SLOC), and light fraction organic carbon (LFOC) have been considered to be suitable indicators (Chen et al., 2012; Sheng et al., 2015). SLOC refers to carbon with high solubility, quick movement and easy mineralization influenced by plants and soil microorganisms (Cao et al., 2013). SLOC includes particulate organic carbon (POC), readily oxidized carbon (ROC), soil microbial biomass carbon (SMBC), dissolved organic carbon (DOC), and light fraction organic carbon (LFOC) (Geng et al., 2009). SLOC has a relatively short turnover time and has shown higher sensitivity to management practices when compared to the total SOC stock. Thus, this pool has been suggested as suitable and sensitive indicator to study the effect of grazing on SOC (Soon et al., 2007; Cao et al., 2013). 
In recent years, simulation models have been recognized as effective tools for decisionmaking and ecosystems management in relation to soil carbon sequestration. The 75 CENTURY model is a process-based ecological model to simulate SOC dynamics, integrating the effects of climate, soil driving variables and management in different ecosystems (croplands, grasslands, forests and savannas) on soil fertility parameters and water dynamics (Parton et al., 1987). The model includes specific options to simulate the effect of grazing on plant production and soil carbon.

About $70 \%$ of Iran's rangelands are located in arid and semi-arid regions, and are generally used as grazing pastures. At present, no specific research has been conducted to simulate the effect of grazing on SOC stocks in semiarid environments, especially in terms of SLOC pools. Bajgah rangeland is one of the semi-arid rangelands of southern Iran that

\section{Materials and methods} after the Iranian Revolution and the establishment of an army garrison around this rangeland and the placement of another part of the rangelands at the Faculty of Agriculture, Shiraz University, these pastures were not grazed after the revolution. Our hypothesis was that no grazing and light grazing would not have a negative effect on soil carbon stock, and with increasing grazing intensity in the long term, soil organic carbon stock and the soil carbon sequestration rate would decrease in these rangelands. If the results of the studies showed us that a type of grazing intensity management cannot have a negative effect on soil carbon, we would be able to propose this type of grazing management to the school authorities, which will not reduce the soil organic carbon stock (soil health), and it can also provide animal husbandry and livestock products. Therefore, the aims of this study are: i) to assess SOC stocks under different scenarios of grazing intensities in semi-arid rangelands of Southern Iran, ii) to simulate the long-term variations of SOC and SLOC pool stocks with the CENTURY model, and iii) to indicate the more effective grazing management.

Study area 
The Bajgah rangelands are located in the northwest of the School of Agriculture Shiraz University (latitude: $29^{\circ} 36^{\prime} \mathrm{N}$, longitude: 52³2' E, elevation: $1820 \mathrm{~m}$ ) in Southern Iran (Figure 1). Based on the 43-year (1972-2014) statistics of the local meteorological station, the average annual precipitation and temperature are $388.4 \mathrm{~mm}$ and $13.4^{\circ} \mathrm{C}$, respectively. The rangelands of Bajgah are classified as semi-arid, and grasses are mainly $\mathrm{C}_{3}$ type. Bromus sp., Agropyron sp., Onobrychis sp., Medicago sp., Hordeum sp., and Poa sp. have been observed predominantly within the studied region. Soils are mainly Fluvisols and moderately deep. The historical management of rangelands belong to three periods: the period before nationalization of forests and rangelands (before 1963), the period of nationalization of rangelands (1963-1979), and the contemporary (Iranian Revolution) period (1979 to present), and includes light grazing, moderate grazing, and no grazing management respectively (Vanaee et al., 2017). After the Iranian Revolution and the change of government and also occurrence of a war between Iran and Iraq, the grazing intensity on rangelands in Iran was increased to produce more food and the supply of meat. But the Bajgah rangelands because they were within the garrison of the army and the lack of permission to enter the ranchers in the area caused the rangelands not to be grazed. The management of Bajgah rangelands has been similar to the rest of Iran until the occurrence

117 of the revolution (that's mean the management of this region has been the same as Vanaee 118 et al. (2017)) and since that time, the grazing of livestock has been eliminated in the Bajgah rangeland. For the present study, four scenarios were selected light grazing (LG) with $25 \%$ of live shoots removed by grazing, moderate grazing (MG) with $50 \%$ of live shoots removed by grazing, heavy grazing ( $\mathrm{HG}$ ) with $75 \%$ of live shoots removed by grazing, and

122 no grazing management. According to surveys with native people, the duration of grazing 123 in the rangelands of Bajgah is four months from the beginning of December to the end of 124 March. 
The CENTURY model simulates the long-term dynamics of C, N, P and S for different ecosystems. This model represents SOC in three conceptual pools: active, passive and slow (Parton et al., 1988) and the sum of carbon in these pools represents the SOC stock (Tornquist et al., 2009). The passive pool contains a high level of lignin, chemically resistant to decomposition and with a long (800-1200 years) turnover time (Parton et al., 1988). Slow pool mainly contains cellulose, hemi-cellulose, and organic matter physically protected inside soil aggregates, with a turnover time of 20-50 years. Active pool contains microorganisms and their products (proteins, amino acids, sugars, and starches) and represents the soil labile organic carbon pool (SLOC), with a turnover time between 2 and 4 years. In the Century model, the total organic carbon of soil is the sum of soil organic carbon contained in the three pools of slow, passive and active. In this study, we considered the soil organic carbon stock in the active pool equivalent to SLOC (however, it appears that the active pool is the same as SLOC). In CENTURY, SLOC is included in a variable called somlc (1) and is highly influenced by management practices such as grazing (Bot and Benites, 2005). The model has three options (GRZEFF $=0,1,2)$ to consider the effect of grazing on grass production (aboveground and below ground), root/shoot ratio and soil carbon. For option $1(\mathrm{GRZEFF}=0)$ there are no direct impacts of grazing on plant production except for the removal of vegetation and return of nutrients by the animals. Option 2 (GRZEFF=1) is referred to as the lightly grazed effect (Holland et al., 1992) and includes a constant root/shoot ratio (not changing with grazing) and a linear decrease in potential plant production with increasing grazing intensity. Option $3(\mathrm{GRZEFF}=2)$ is referred to as the heavy grazed (Holland et al., 1992) option, and includes a complex grazing optimization curve for aboveground plant production. These options are adjusted by some parameters available in the CROP.100 file (Parton et al., 1987). The input data to the CENTURY model are included in 12 files, each containing a specific set of variables (Figure 2).

\section{Sampling and laboratory measurements}


Previous soil organic carbon measurements were available for 1987, 1995, 1996, 2010 and 2012 (30, 30, 45, 40 and 30 samples, respectively) under no grazing management. In the present research, an additional soil sampling on the same area (4000 ha) was carried out from September to December 2014. A simple random sampling was adopted to collect independent and unbiased samples as well as remain within the limits of time, money, and staff available for sampling. After removing the litter layer, 90 soil samples were taken from the top soil $(0-20 \mathrm{~cm})$. Soil samples were air dried, visible plant materials were removed, and the analyses were made on the $<2 \mathrm{~mm}$ dried soil fraction after sieving. Particle-size distribution, soil reaction, soil organic carbon, and total soil nitrogen were determined by the Hydrometry method (Bouyoucos, 1962), pH meter, Walkley and Black method (Walkley and Black, 1934), and Kjeldahl method (Bremner et al., 1982) respectively. To determine the soil bulk density, two soil core samples (in addition to routine soil samples) were collected in each sampling point using the Core method (Blake and Hartge, 1986). Finally, SOC stock was calculated in the 0-20 cm layer using Eq. (1):

$$
\text { SOC Stock }=\text { OC }(\%) \times \text { layer thickness }(\mathbf{c m}) \times \text { bulk density }\left(\mathrm{g} \mathrm{cm}^{-3}\right)
$$

For vegetation measurements, first the proper number of plots was determined to collect representative data. Thereafter, 17 quadrats (plots) with dimensions of $1 \times 1 \mathrm{~mm}$ were randomly established throughout the rangelands. Then vegetation sampling was carried out during the main growing season from May to July 2014. In each plot, litter and plant biomass (above and below ground) samples were dried at $60^{\circ} \mathrm{C}$ for $48 \mathrm{~h}$ and weighed. Thereafter, $2 \mathrm{~g}$ samples were oven ashed at $550^{\circ} \mathrm{C}$ for $6 \mathrm{~h}$, and plant carbon and the total plant nitrogen were measured using the ash weight, primary weight, and ratio of organic carbon to organic material relationship (Birdsey et al., 2000) and Kjeldahl method (Kirk, 1950), respectively.

\section{Model initialization}


In this study, the CENTURY model version 4.0 (Parton et al., 1987) was used to simulate SOC stock and SLOC stock. Values of monthly mean maximum and minimum temperatures and precipitation were obtained from the 43-year (1972-2014) statistics of the meteorological station of the College of Agriculture in Shiraz University. Data on climatic parameters for future simulation periods were stochastically generated by CENTURY model based on the skewed distribution of climate data (Wang et al., 2008; Tornquist et al., 2009) from 1972 to 2014. The site-specific parameters and the soil and plant cover parameters are shown in Table 1 . The physiological and ecological parameters for $\mathrm{C}_{3}$ plants were specified in the CROP file of the model.

\section{Model calibration}

CENTURY model is able to simulate total soil organic carbon (SOC) and carbon pools under the equilibrium state (Tornquist et al., 2009), that is a method to run the model for an initial period (7000-10000 years) based on the conditions of soil and vegetation before any anthropic disturbance (Kamoni et al., 2007). The equilibrium condition represents the baseline for the evaluation of the management effects on soil organic carbon in the ecosystem. Therefore, the user should first determine the conditions of "equilibrium" and then import them to the CENTURY model. In this research, the CENTURY model was run for 10,000 years considering (Tornquist et al., 2009; Wilson et al., 2009) that the Bajgah rangelands have been under coverage of $\mathrm{C}_{3}$ grasses and light grazing before 1963 . Then, the CENTURY model was run for the periods after 1963. Finally calibrated using the data obtained from previous samplings (following the initial sampling in 1987). The calibration process included repetitive running of the model and reviewing the model outputs, then adjusting the model's default parameters until measured carbon (Table 1) was equal to the simulated SOC stock (Tornquist et al., 2009; Wilson et al., 2009).

\section{Model validation}

SOC data measured in September and December 2014, as well as the data of the previous sampling (1995, 1996, 2010 and 2012) were used for the model validation (265 
208

209

210

211

212

213

214

215

216

217

218

219

220

221

222

223

224

225

226

227

228

229

230

231

232

22

data). To validate the model, we compared the model output to a set of data independent from the calibration stage. Certainly, the data that was measured in this study was in a no grazing management.

The SOC stock data are inserted into Century model on an average basis and this is one of the defects of the Century model that does not consider spatial distribution and works based on the central indices (the Century model based on mean). Finally, we will have 6 pairs (or 6 points) of data due to the use of 6 sampling times to model validation. Some statistical comparisons between the simulated and measured values including determination factor $\left(\mathrm{R}^{2}\right)$, correlation coefficient (r), root mean square error (RMSE) (Eq. 2), RMSE 0.05 (Eq. 3) and modelling efficiency (EF) (Eq. 4) were used for model validation where $\mathrm{O}_{\mathrm{i}}, \mathrm{P}_{\mathrm{i}}, \overline{\mathrm{O}}, \mathrm{SE}_{\mathrm{i}}$, $\mathrm{t}_{\mathrm{m} 0.95}$, and $\mathrm{n}$ are the observed value, simulated value, the mean of observed values, the standard deviation of the observed values, $t$-student value (95\% probability level), and the number of observations, respectively.

1

$$
\begin{aligned}
& \text { RMSE }=\frac{100}{\overline{0}} \times \sqrt{\frac{\sum_{i=1}^{n}\left(\mathbf{O}_{i}-P_{i}\right)^{2}}{n}} \\
& \operatorname{RMSE}_{0.05}=\frac{100}{\overline{0}} \sqrt{\frac{\sum_{i=1}^{n}\left(S E_{i} \times t_{m 0.95}\right)^{2}}{n}} \\
& \text { EF }=1-\frac{\sum_{i=1}^{n}\left(P_{i}-\mathbf{O}_{i}\right)^{2}}{\sum_{i=1}^{n}\left(\mathbf{O}_{i}-\overline{\mathbf{0}}\right)^{2}}
\end{aligned}
$$

\section{Simulation of grazing scenarios}

To investigate the effect of different scenarios of grazing intensities on SOC and SLOC stocks, the model was run in the four different grazing scenarios from 2015 to 2100 in the rangelands of Bajgah: no grazing, light grazing, moderate grazing and heavy grazing. To test the effect of different scenarios of grazing intensity on the simulated parameters, LSD test was used. All statistical analyses were carried out by SPSS software.

\section{Results}




\section{Model calibration and validation}

The model default parameters were adjusted during the calibration until the simulated SOC stock with a value of $3251.6\left(\mathrm{~g} \mathrm{~m}^{-2}\right)$ was close to the measured value of $3228.5\left(\mathrm{~g} \mathrm{~m}^{-}\right.$

${ }^{2}$ ) in 1987 representing the original levels of SOC stock. Thus, the CENTURY model was considered suitable for simulating the dynamics of SOC of the study area. The comparison of variations in the carbon pools curves during the equilibrium period (Figure 3) indicated that the slow and active carbon pools increased rapidly during the first 300 and 100 years, respectively, while the passive pool decreased slowly throughout the entire equilibrium period. At the equilibrium state, the fractions of slow, active, and passive organic carbon pools were $50 \%, 3.8 \%$, and $46.2 \%$ of the total SOC respectively.

There was a significant linear relationship $\left(\mathrm{R}^{2}=0.86\right)$ between measured and simulated SOC stocks (Figure 4), and the correlation coefficient (r) was 0.93 (Table 2). The root mean square error (RMSE), that indicates the total difference between the measured and simulated values, was lower than $\mathrm{RMSE}_{0.05}$, also EF (modelling efficiency) was $83 \%$ (Table 2), thus the observed and simulated data are not significantly different. Overall, results indicate that the CENTURY model accurately simulates the dynamics of SOC stock in the Bajgah rangelands (Figure 4).

\section{Changes of SOC stocks under grazing}

Long-term changes of SOC stocks in response to grazing until 2100 showed significant differences ( $\mathrm{p}<0.01)$, and the minimum $\left(2883.4 \mathrm{~g} \mathrm{~m}^{-2}\right)$ and maximum $\left(3436.2 \mathrm{~g} \mathrm{~m}^{-2}\right) \mathrm{SOC}$ stocks were observed in the heavy and no grazing scenarios (Table 3). Figure 5 shows the trend of changes in the SOC stocks from 1963 to 2014, followed by the variations of SOC stock from 2015 to 2100 under the four different grazing scenarios.

The simulations showed that the SOC stocks during the years from 2015 to 2100 increased by $2.7 \%$ under no grazing and by $1.7 \%$ under the light grazing scenario, but there was no significant difference $(\mathrm{p}<0.01)$ between them (Table 3 and Figure 5). However, despite the higher increase of SOC stock in the no grazing scenario compared to the light 
grazing scenario, both changes were not significant in relation with the baseline year (2014) (Table 3).

At higher grazing intensities, SOC stocks decreased significantly in the two scenarios of moderate and heavy grazing in comparison with the no grazing and light grazing scenarios (Table 3 and Figure 5). The simulations indicated that SOC stocks decreased by 23.4 and $24.6 \%$ in 2100 compared to 2014 under the scenarios of moderate and heavy grazing, respectively (Table 3). Despite the considerable reduction of SOC stocks under the moderate and heavy grazing scenarios, no significant difference was observed between them (Table 3).

\section{Changes of SLOC stock under grazing}

The simulation of soil labile organic carbon (SLOC) stocks across the different grazing scenarios (Table 4) indicated significant differences among all scenarios $(\mathrm{p}<0.01)$. Figure 6 shows the annual variations of SLOC stock from 1963 to 2014, and then from 2015 until 2100 under the different grazing scenarios. Simulations also indicated that SLOC stocks will be decreased by $26.1,59.6$, and $70 \%$ in the light, moderate, and heavy grazing scenarios respectively, compared to the no grazing scenario (Table 4).

\section{Discussion}

The results of validation indicated that the CENTURY model was able to simulate the changes of SOC (Table 2), and can be applied for the long-term simulation of the SOC changes in semi-arid rangelands of Bajgah. Wang et al. (2008) by using a validated Century model simulated the effects of different grazing intensities on SOC changes in Northeast China, and results showed that SOC will keep constant at lower grazing intensities. So far, different studies indicated the capability of the Century model for SOC simulation in rangelands for example Zhang et al. (2007) in grasslands on the Qinghai-Tibetan Plateau under alpine climatic conditions, Brown et al. (2010) in rangelands of southwestern United States, Vanaee et al. (2017) in different meadows of Kurdistan province with continental climate and high rainfall. 
The simulation results showed increased SOC stocks by adopting the no grazing management in the Bajgah rangelands (Figure 5). No grazing has an enhanced canopy cover and a high density of litter (Shifang et al., 2008), aboveground and below-ground litter accumulation (Chen et al., 2012), and a positive effect on improvement of vegetation diversity (Al-Rowaily et al., 2015) that finally lead to greater SOC stocks (Derner and Schuman, 2007; Mekuria et al., 2007; Chen et al., 2012). Most studies have reported increased soil carbon levels by applying no grazing management, in agreement with the results obtained from this study (Mekuria et al., 2007; Chen et al., 2012). Nevertheless, 295 other researches have shown that soil organic carbon may increase under grazing compared 296 to no grazing management due to the $\mathrm{C}$ immobilization in the excessive plant litter material, and the development of annual grasses with a different rooting system favoring organic matter accumulation (Reeder et al., 2002; Orgill et al., 2016). Waters et al. (2016) argued 299 that the soil inherent properties, the climate, the landscape morphology and position, and also the composition of the vegetation community are involved in the difference of the 301 ecosystem's carbon response to the no grazing management.

In the Bajgah rangelands, long-term simulations indicated that the light grazing intensity presents increased SOC stocks compared to moderate and heavy grazing (Figure 5), with not significant difference compared with the no grazing scenario (Table 3). Wang 305 et al. (2001) stated that appropriate grazing decreases the amount of the mature and old 306 tissues of the plant, and therefore improves the photosynthetic rate of the plant leaves remained after grazing, as well as the cycle of nutrients and water in the plant. Wright et al. 308 (2004) reported that long-term grazing at low grazing intensity of Bermuda-grass pastures can increase SOC and SON concentrations and could have strong potential for $\mathrm{C}$ and $\mathrm{N}$ sequestration. This is mainly due to enhanced turnover of plant material and excreta under 311 low grazing intensity. Mcsherry and Ritchie (2013) also demonstrated that in the sites 312 where $\mathrm{C}_{3}$ grasses are predominant, light grazing leads to increased SOC stocks, thus 313 supporting the results obtained from this study. Some studies reported that light grazing 314 intensity was a useful management for enhancing C sequestration (Da Silva et al., 2014). 
315 Cecagno et al. (2018) showed a higher potential of the soil for $\mathrm{C}$ sequestration with a low grazing intensity.

The long-term simulation of different scenarios of grazing from 2015 to 2100, demonstrated also that as the grazing intensity increases, SOC stocks would decrease (Figure 5). Other recent studies stated that the change of the SOC stocks of rangelands in response to grazing is dependent on the grazing intensity (Mcsherry and Ritchie, 2013; Ritchie, 2014; Papanastasis et al., 2015). In this study, the simulations indicated a SOC stock reduction from 2015 until 2100 in the two scenarios of moderate (with 50\% of live shoots removed by grazing) and heavy grazing (with $75 \%$ of live shoots removed by grazing) (Figure 5); and percent reduction of SOC stocks was 23.4 and 24.6, respectively (Table 3). Wang et al. (2008), by using Century model showed that high grazing intensities would have higher probability to release more carbon into atmosphere, thus grassland ecosystems would act as a carbon source. They also showed that when $40 \%$ live shoots were removed by grazing event per month, about $20 \%$ soil organic carbon was lost in good agreement with our results. Vanaee et al. (2017) in Dehgolan meadows in Kurdistan province (in west of Iran) by using Century model predicted that SOC stock under moderate grazing and high grazing in the period from 2014 to 2100 will be reduced by 23 and 25 percent, respectively. Their results were very close to our study results.

Increased grazing intensity leads to a decreased carbon input from litterfall due to vegetation destruction of plant cover and consumption of litter by herbivores, a reduction of leaves, an increase of soil temperature in the areas where soil is bare, and the development of proper conditions for microbial decomposition (Abril and Bucher, 2001). All of these factors lead to lowered SOC stocks (Derner et al., 2006; Wang et al., 2008).

Some studies have reported a negative effect of grazing on SOC in regions with precipitation lower than $600 \mathrm{~mm}$ per year (Golluscio et al., 2009). Pineiro et al. (2010) stated that the levels of SOC under semi-arid climate conditions decrease under grazing. According to Mcsherry and Ritchie (2013) the intensity of grazing and the type of grass are the most important factors regulating SOC in rangelands after environmental variables. 
343 Furthermore, decreased SOC levels with increased grazing intensity in rangelands where $344 \mathrm{C}_{3}$ grasses are predominant have been reported by other researches (Potter et al., 2001). 345 Mcsherry and Ritchie (2013) also suggest that grazing in the rangelands where $\mathrm{C}_{3}$ grasses 346 are predominant, under moderate and heavy grazing conditions, has a negative effect on 347 the soil organic carbon. Considering that in the semi-arid rangelands of Bajgah annual 348 precipitation is lower than $600 \mathrm{~mm}$ per year, and the dominant grasses are of $\mathrm{C}_{3}$ type, the 349 350 decreased levels of SOC stock under moderate and heavy grazing conditions in these rangelands is reasonable and in agreement with the existing literature.

The results of the simulation indicated decreased levels of soil labile organic carbon (SLOC) with increased grazing intensity in the Bajgah rangelands (Figure 6). Cao et al. (2013) also stated that with increased grazing intensity, the SLOC stocks would reduce. The SLOC stocks decreased by 59.6 and $70 \%$ under moderate and heavy grazing scenarios respectively, in comparison with the no grazing scenario (Table 4). Although only a few studies are available on the effect of grazing on SLOC, Chen et al. (2012) indicated that SLOC stocks in grazed sites is $73.3 \%$ less than in no grazing sites, and this finding is close and in agreement with our results.

Although the amount of SOC stocks had no significant difference between the light grazing and no grazing scenarios, as well as between moderate and heavy grazing scenarios (Table 3), there was a significant difference $(\mathrm{p}<0.01)$ among the levels of SLOC stocks in all grazing scenarios (Table 4). In addition, the annual changes of the SLOC pools in comparison with the annual variations of SOC stocks showed that SLOC is more sensitive to grazing and it responds much faster to grazing than SOC (Figure 5 and 6). Accordingly, the SLOC stock can be proposed as a proper and sensitive parameter to be preferred to SOC stock for researches on grazing intensity. Due to the slow reaction of the SOC stock (Medina-Roldán et al., 2012), the majority studies have proposed the SLOC as a proper parameter to study the grazing effects on soil carbon (Soon et al., 2007; Cao et al., 2013).

\section{Conclusions}


In this research, a reduction of SOC and SLOC stocks with the increase of grazing 371 intensity was observed in semi-arid rangelands of Bajgah (Southern Iran). The long-term 372 simulation of light grazing had not a significant decreasing effect on the SOC stock. 373 Therefore, light grazing management is recommended in Bajgah rangelands. Furthermore, 374 this research suggests and confirms the effectiveness of SLOC stock as a sensitive and 375 proper parameter for the investigation of different grazing scenarios effects in the future 376 research.

377 Author contribution Contributions of all authors to this work were as 378 follows:

379 Sayed Fakhreddin AFZALI: Conceptualization, writing — original draft and editing

Bijan AZAD: Conceptualization, writing-original draft

381

Rosa FRANCAVIGLIA : writing , Literature reviewing

382

383

Funding No funding has been received for the current study.

Data availability The datasets used and analyzed during this article are

385 available from the corresponding author on reasonable request.

Declarations

387 Ethics approval and consent to participate Not applicable.

388 Consent for publication Not applicable.

389 Competing interests The authors declare that they have no competing

390 interests.

\section{References}

Abril, A.; Bucher, E.H. Overgrazing and soil carbon dynamics in the western Chaco of Argentina. Appl. Soil Ecol. 2001, 16 (3), 243-249. open grazing and livestock exclusion on floristic composition and diversity in natural ecosystem of Western Saudi Arabia. Saudi J. biol. Sci. 2015, 22(4), 430-437. 
Birdsey, R.; Heath, I.S.; Williams, D. Estimation of carbon budget model of the United States forest sector. Advances in Terrestrial Ecosystem carbon Inventory, Measurements, and Monitoring Conference in Raleigh, North Carolina, October 3-5, 2000, 51-59.

Blake, G.R.; Hartge, K.H. Bulk density. Methods of Soil Analysis. Part 1. Physical and mineralogical methods. Soil Sci. Soc. Am. Pub. 1986; pp. 363-376.

Bot, A.; Benites, J.; 2005. The importance of soil organic matter: Key to drought-resistant soil and sustained food production. Food Agriculture Organization of the United Nations, Rome, 2005, p. 95. Bouyoucos, G.J. Hydrometer method improved for making particle size analyses of soils. Agron. J. 1962, 54 (5), 464-465.

Bremner, G.J.; Mulvaney, C.S. Nitrogen total. In: Page, A.L.; Miller, R.H.; Keenry, R.R. (Eds.), Methods of soil analysis, part 2. Seconded. American Society of Agronomy, Madison, WI, 1982, pp.595-624.

Brown, J.; Angerer, J.; Salley, S.W.; Blaisdell, R.; Stuth, J.W. Improving estimates of rangeland carbon sequestration potential in the US Southwest. Rangeland Ecol. Manage. 2010, 63 (1), 147-154.

Cecagno1, D.; Veloso Gomes, M.; Andrade Costa, S.E.V.G.; Martins, A.P.; Oliveira Denardin, L.G.; Bayer, C.; Anghinoni, I.; Faccio Carvalho, P.C. Soil organic carbon in an integrated crop-livestock system under different grazing intensities. Rev. Bras. Cienc. Agrar. 2018, 13, 1-7.

Cao, J.; Wang, X.; Sun, X.; Zhang, L.; Tian, Y. Effects of grazing intensity on soil labile organic carbon fractions in a desert steppe area in Inner Mongolia. SpringerPlus 2013, 2 (1), 1-8.

Chen, Y.; Li, Y.; Zhao, X.; Awada, T.; Shang, W.; Han, J. Effects of Grazing Exclusion on Soil Properties and on Ecosystem Carbon and Nitrogen Storage in a Sandy Rangeland of Inner Mongolia, Northern China. Environ. Manage. 2012, 50, 622-632.

Da Silva, F.D.; Amado, T.J.C.; Ferreira, A.O.; Assmann, J.M.; Anghinoni, I.; De Faccio Carvalho, P.C. Soil carbon indices as affected by 10 years of integrated crop-livestock production with different pasture grazing intensities in Southern Brazil. Agric. Ecosyst. Environ. 2014, 190, 60-69.

Derner, J.D.; Boutton, T.W.; Briske, D.D. 2006. Grazing and ecosystem carbon storage in the North American Great Plains. Plant Soil, 2006, 280 (1-2), 77-90.

Derner, J.; Schuman, G. Carbon sequestration and rangelands: a synthesis of land management and precipitation effects. J. Soil Water Conserv. 2007, 62 (2), 77-85.

Geng, Y.Q.; Yu, X.X.; Yue, Y.J.; Li, J.H.; Zhang, G.Z. Active organic carbon pool of coniferous and broad-leaved forest soils in the mountainous areas of Beijing. For. Stud. China 2009, 11 (4), 1-6. 
Golluscio, R.; Austin, A.; Martinez, G.; Gonzalez, P.M.; Sala, O.; Jackson, R. Sheep grazing decreases carbon and nitrogen pools in the Patagonian Steppe: combination of direct and indirect effects. Ecosyst. 2009, 12, 686-697.

Holland, E.A.; Parton, W.J.; Detling, J.K.; Coppock, D.L. Physiological responses of plant populations to herbivory and their consequences for ecosystem nutrient flow. Am. Nat. 1992, 140 (4), 685706.

Kamoni, P.; Gicheru, P.; Wokabi, S.; Easter, M.; Milne, E.; Coleman, K.; Falloon, P.; Paustian, K.; Killian, K.; Kihanda, F. Evaluation of two soil carbon models using two Kenyan long term experimental datasets. Agric. Ecosyst. Environ. 2007, 122, 95-104.

Kirk, P.L. Kjeldahl method for total nitrogen. Anal. Chem. 1950, 22 (2), 354-358.

Lal, R.. Carbon sequestration. Philos. Trans. Roy. Soc. 2008, 363, 815-830.

Mcsherry, M.E.; Ritchie, M.E. Effects of grazing on grassland soil carbon: a global review. Global change biol. 2013, 19 (5), 1347-1357.

Medina-Roldán, E., Paz-Ferreiro, J.; Bardgett, R.D. Grazing exclusion affects soil and plant communities, but has no impact on soil carbon storage in an upland grassland. Agric. Ecosyst. Environ. 2012, 149, 118-123.

Mekuria, W.; Veldkamp, E.; Haile, M.; Nyssen, J.; Muys, B.; Gebrehiwot, K. Effectiveness of exclusions to restore degraded soils as a result of overgrazing in Tigray, Ethiopia. J. Arid Environ. 2007, 69 (2), 270-284.

Muñoz-Rojas, M.; Doro, L.; Ledda, L.; Francaviglia, R. Application of CarboSOIL model to predict the effects of climate change on soil organic carbon stocks in agro-silvo-pastoral Mediterranean management systems. Agric. Ecosyst. Environ. 2015, 202, 8-16.

Orgill, S.E.; Condon, J.R.; Conyers, M.K.; Morris, S.G.; Alcock, D.J.; Murphy, B.W.; Greene. R.S.B. Removing grazing pressure from a native pasture decreases soil organic carbon in southern new south wales, australia. Land Degrad Dev. 2016, 29 (2), 274-283.

Papanastasis, V.P.; Bautista, S.; Chouvardas, D.; Mantzanas, K.; Papadimitriou, M.; Mayor, A.G.; Koukioumi, P.; Papaioannou, A.; Vallejo, R.V. Comparative assessment of goods and services provided by grazing regulation and reforestation in degraded mediterranean rangelands. Land Degrad. Dev. 2015, 28 (4), 1178-1187.

Parton, W.J.; Schimel, D.S.; Cole, C.; Ojima, D. Analysis of factors controlling soil organic matter levels in Great Plains grasslands. Soil Sci. Soc. Am. J. 1987, 51 (5), 1173-1179.

Parton, W.J.; Stewart, J.W.; Cole, C.V. Dynamics of C, N, P and S in grassland soils: a model. Biogeochem. 1988, 5 (1), 109-131. 
Pineiro, G., Paruelo, J.M.; Oesterheld, M.; Jobbágy, E.G. Pathways of grazing effects on soil organic carbon and nitrogen. Rangeland Ecol. Manage. 2010, 63 (1), 109-119.

Potter, K.; Daniel, J.; Altom, W.; Torbert, H. Stocking rate effect on soil carbon and nitrogen in degraded soils. J. soil water conserv. 2001, 56, 233-236.

Reeder, J.; Schuman, G. Influence of livestock grazing on C sequestration in semi-arid mixed-grass and short-grass rangelands. Environ. Pollut. 2002, 116 (3), 457-463.

Ritchie, M.E. Plant compensation to grazing and soil carbon dynamics in a tropical grassland. PeerJ 2014, 2:e233, 1-27.

Sepe, L.; Salis, M.; Francaviglia, R.; Fedrizzi, M.; Carroni, A.M.; Sabia, E.; Bruno, A.; Rufrano, D.; Ruda, P.; Dell'Abate, M.T.; Alianello, A.; Veloccia, M.; Masetti, O.; Renzi, G.; Fanigliulo, R.; Pagano, M.; Sperandio, G.; Guerrieri, M.; Puri, D.; Claps, S. Environmental effectiveness of the cross compliance Standard 4.6 'Minimum livestock stocking rates and/or appropriate regimens'. Ital. J. Agron. 2015, 10 (1), 1-9.

Sheng, H.; Zhou, P.; Zhang, Y.; Kuzyakov, Y.; Zhou, Q.; Ge, T.; Wang, C. Loss of labile organic carbon from subsoil due to land-use changes in subtropical China. Soil Biol. Biochem. 2015, 88, 148157.

Shifang, P.; Hua, F.; Changgui, W. Changes in properties and vegetation following exclusion and grazing in degraded Alxa desert steppe of Inner Mongolia, China. Agric. Ecosyst. Environ. 2008, 124, 33-39.

Smith, P.; Fang, C.; Dawson, J.; Moncreiff, J. Impact of global warming on soil organic carbon. Adv Agron. 2008, 97, 1-43.

Soon, Y.; Arshad, M.; Haq, A.; Lupwayi, N. The influence of 12 years of tillage and crop rotation on total and labile organic carbon in a sandy loam soil. Soil Tillage Res. 2007, 95 (1), 38-46.

Tornquist, C.G.; Mielniczuk, J.; Cerri, C.E.P. Modeling soil organic carbon dynamics in Oxisols of Ibirubá (Brazil) with the Century Model. Soil Tillage Res. 2009, 105 (1), 33-43.

Vanaee, F.; Karami, P.; Joneydi Jafari, H.; Nabialahi, K. Simulation of soil organic carbon dynamic in meadow ecosystems under different management practices using CENTURY model. J. Rangeland 2017, 10 (4), 439-449.

Walkley, A.; Black, I.A. An examination of the Degtjareff method for determining soil organic matter, and a proposed modification of the chromic acid titration method. Soil sci. 1934, 37, 29-38.

Wang, M.J.; Wan, X.R.; Zhong, W.Q. The interaction between the vegetarian and plant. Chin. J. Ecol. 2001, 20 (5), 39-43. 
567

568

569

Wang, Y.; Zhou, G.; Jia, B. Modeling SOC and NPP responses of meadow steppe to different grazing intensities in Northeast China. Ecol. Modell. 2008, 217, 72-78.

Waters, C.M.; Orgill, S.E.; Melville, G.J.; Toole, I.D.; Smith, W.J. Management of grazing intensity in the semi-arid rangelands of southern australia - effects on soil and biodiversity. Land Degrad. Dev. 2016, 28 (4), 1363-1375.

Wilson, C.; Papanicolaou, A.; Abaci, O. SOM dynamics and erosion in an agricultural test field of the Clear Creek, IA watershed. Hydrol. Earth Syst. Sci. Discuss. 2009, 6 (2), 1581-1619.

Wright, I.J.; Reich, P.B.; Westoby, M.; Ackerly, D.D.; Baruch, Z.; Bongers, F.; Cavender Bares, J.; Chapin, T.; Cornelissen, J.H.C.; Diemer, M.; Flexas, J.; Garnier, E.; Groom, P.K.; Gulias, J.; Hikosaka, K.; Lamont, B.B.; Lee, T.; Lee, W.; Lusk, C.; Midgley, J.J.; Navas, M.L.; Niinemets, U.; Oleksyn, J.; Osada, N.; Poorter, H.; Poot, P.; Prior, L.; Pyankov, V.I.; Roumet, C.; Thomas, S.C.; Tjoelker, M.G.; Veneklaas, E.J.; Villar, R. The worldwide leaf economics spectrum. Nat. 2004, 428, 821-827.

Zhang, Y.; Tang, Y.; Jiang, J.; Yang, Y. Characterizing the dynamics of soil organic carbon in grasslands on the Qinghai-Tibetan Plateau. Sci. China Ser D: Earth Sci. 2007, 50, 113-120. 
570 Table 1. Soil and vegetation characteristics and climatic parameters used as inputs for the 571 CENTURY model.

\begin{tabular}{|c|c|}
\hline Parameter & Value \\
\hline Location & $52^{\circ} \mathrm{N}, 29^{\circ} \mathrm{E}$ \\
\hline Precipitation (mm) & 388.44 \\
\hline Temperature $\left(\mathrm{C}^{\circ}\right)$ & 13.4 \\
\hline Sand $(\%)$ & 12.72 \\
\hline Silt (\%) & 53.38 \\
\hline Clay $(\%)$ & 33.88 \\
\hline Bulk density $\left(\mathrm{Mg} \mathrm{m}^{-3}\right)$ & 1.265 \\
\hline $\mathrm{pH}$ & 7.93 \\
\hline Field capacity $(\mathrm{FC} \mathrm{v/v} \%)^{\mathrm{a}}$ & 0.383 \\
\hline Wilting point $(\mathrm{WP} v / \mathrm{v} \%)^{\mathrm{a}}$ & 0.159 \\
\hline Initial total SOC $\left(\mathrm{g} \mathrm{m}^{-2}\right)^{\mathrm{b}}$ & 3228.53 \\
\hline Soil C/N & 11.6 \\
\hline Litter carbon $\left(\mathrm{g} \mathrm{m}^{-2}\right)$ & 29.469 \\
\hline Aboveground biomass carbon $\left(\mathrm{g} \mathrm{m}^{-2}\right)$ & 38.947 \\
\hline Belowground biomass carbon $\left(\mathrm{g} \mathrm{m}^{-2}\right)$ & 56.401 \\
\hline Aboveground biomass nitrogen $\left(\mathrm{g} \mathrm{m}^{-2}\right)$ & 1.121 \\
\hline Belowground biomass nitrogen $\left(\mathrm{g} \mathrm{m}^{-2}\right)$ & 1.646 \\
\hline Litter $\mathrm{C} / \mathrm{N}$ & 34.72 \\
\hline
\end{tabular}

572 a data provided by the Water Engineering Department of Agricultural College; ${ }^{\mathrm{b}}$ Average of 30 samples in 1987.

573

574 Table 2. Quantitative statistical analysis between measured and simulated SOC stocks.

\begin{tabular}{lllll}
\hline $\mathrm{R}$ & $\mathrm{R}^{2}$ & $\mathrm{RMSE}_{0.05}$ & $\mathrm{RMSE}$ & $\mathrm{EF}$ \\
\hline 0.93 & 0.86 & 7.07 & 2.35 & $83 \%$ \\
\hline
\end{tabular}


579 Table 3. Long-term changes of SOC stocks under the different grazing intensity scenarios (2015580 2100).

\begin{tabular}{cccc}
\hline Scenario & $\begin{array}{c}\text { SOC stock in 2014 } \\
\left(\mathrm{g} \mathrm{m}^{-2}\right)\end{array}$ & $\begin{array}{c}\text { SOC stock in 2100 } \\
\left(\mathrm{g} \mathrm{m}^{-2}\right)\end{array}$ & $\begin{array}{c}\text { Changes compared to } \\
2014(\%)^{*}\end{array}$ \\
\hline No grazing & 3356.1 & $3446.7^{\mathrm{a}}$ & +2.7 \\
LG & 3356.1 & $3412.5^{\mathrm{a}}$ & +1.7 \\
MG & 3356.1 & $2570.4^{\mathrm{b}}$ & -23.4 \\
HG & 3356.1 & $2529.8^{\mathrm{b}}$ & -24.6
\end{tabular}

581 Values followed by the same letter are not significantly different among grazing scenarios at p<0.01 (LSD tests);

582 SOC soil organic carbon; LG light grazing; MG moderate grazing; HG heavy grazing.

$583 *$ Changes compared to 2014 (\%) calculated as [100 $\times$ (SOC stock in 2100- SOC stock in 2014)/ SOC stock in 2014] 
585 Table 4. Long-term changes of SLOC stocks under the different grazing intensity scenarios 586 (2015-2100).

\begin{tabular}{ccc}
\hline Scenario & SLOC stock $\left(\mathrm{g} \mathrm{m}^{-2}\right)$ & $\begin{array}{c}\text { Changes compared to No grazing } \\
(\%)\end{array}$ \\
\hline No grazing & $20.87 \mathrm{a}$ & 0 \\
$\mathrm{LG}$ & $15.43 \mathrm{~b}$ & -26.06 \\
$\mathrm{MG}$ & $8.43 \mathrm{c}$ & -59.6 \\
$\mathrm{HG}$ & $6.27 \mathrm{~d}$ & -69.95
\end{tabular}

587 Values followed by the same letter are not significantly different among grazing scenarios at $\mathrm{p}<0.01$; SLOC soil 588 labile organic carbon; LG light grazing; MG moderate grazing; HG heavy grazing.

589

590

591 


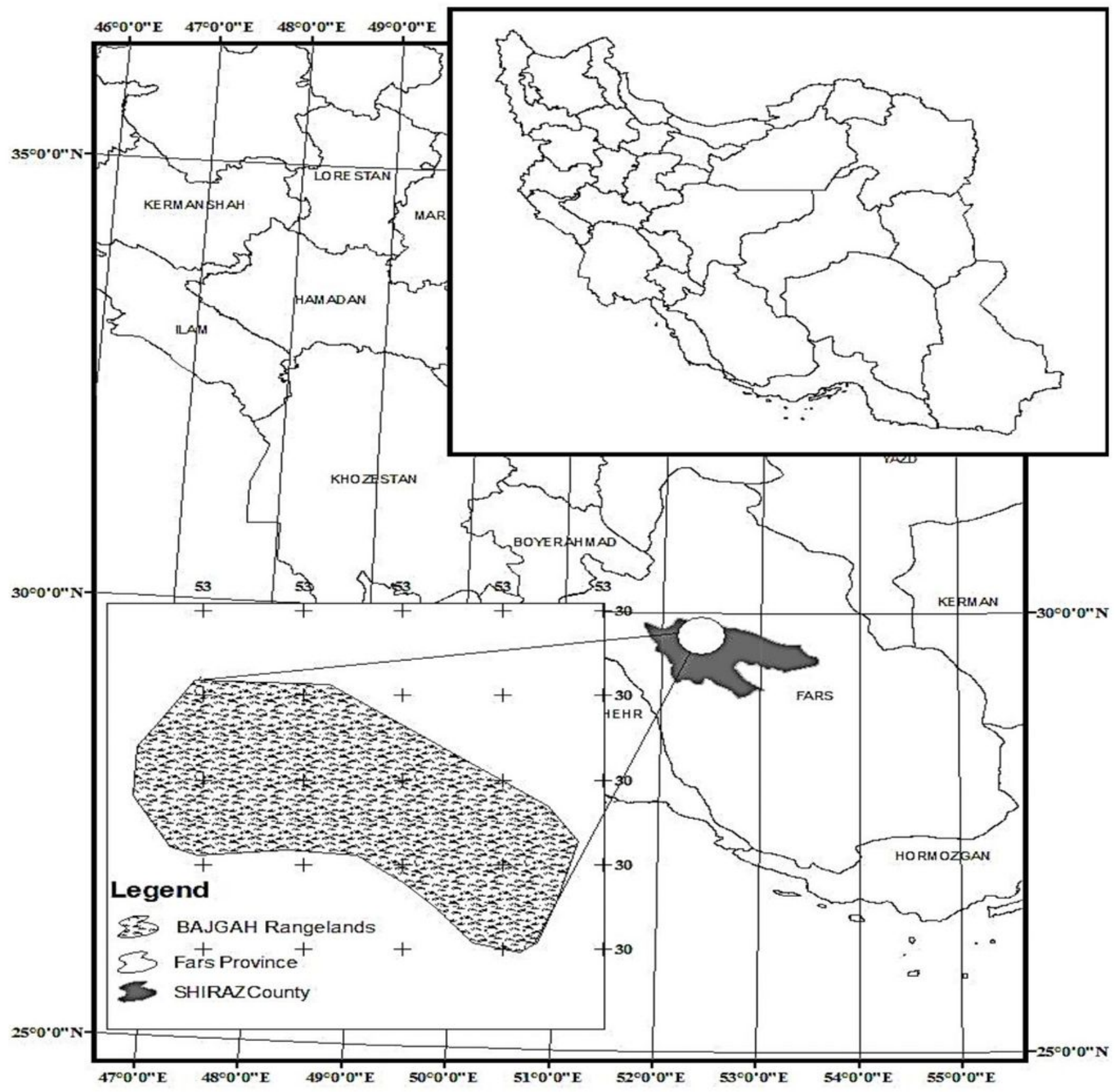

Figure 1

Bajgah region in the South of Iran, Shiraz County, province of Fars. Note: The designations employed and the presentation of the material on this map do not imply the expression of any opinion whatsoever on the part of Research Square concerning the legal status of any country, territory, city or area or of its authorities, or concerning the delimitation of its frontiers or boundaries. This map has been provided by the authors. 


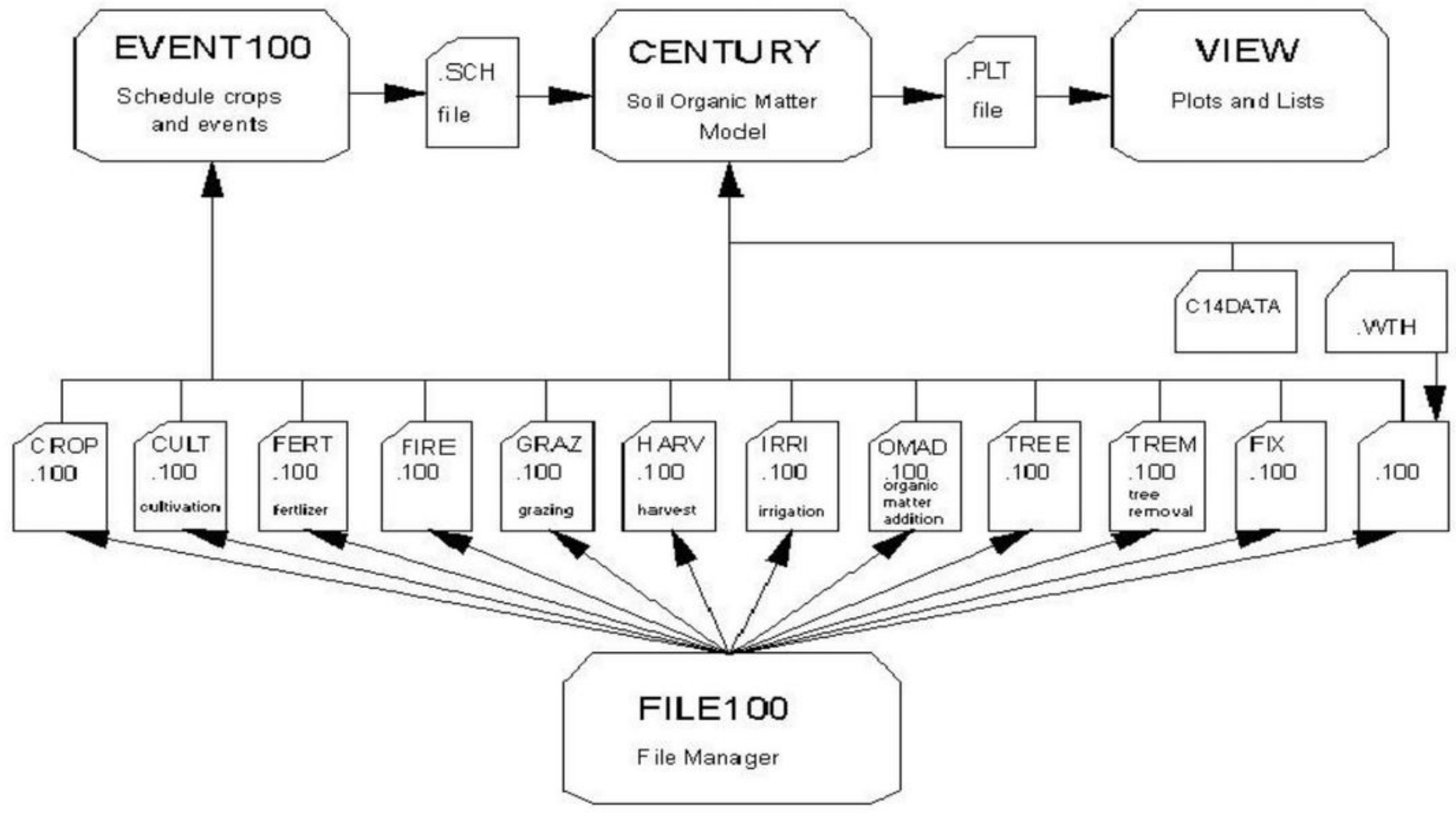

Figure 2

The Century model flowchart.

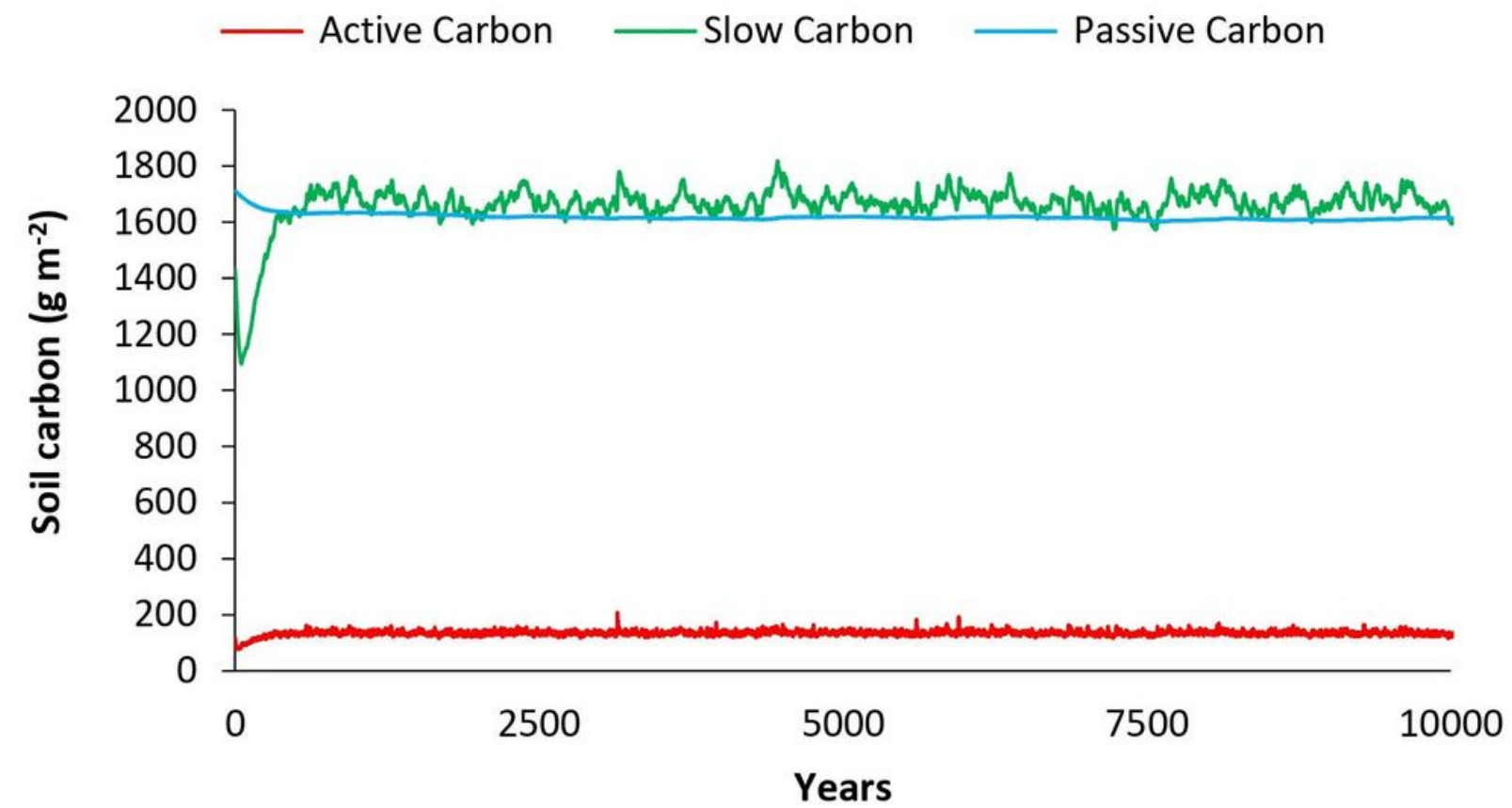

Figure 3

Change of carbon pools during the equilibrium state process. 


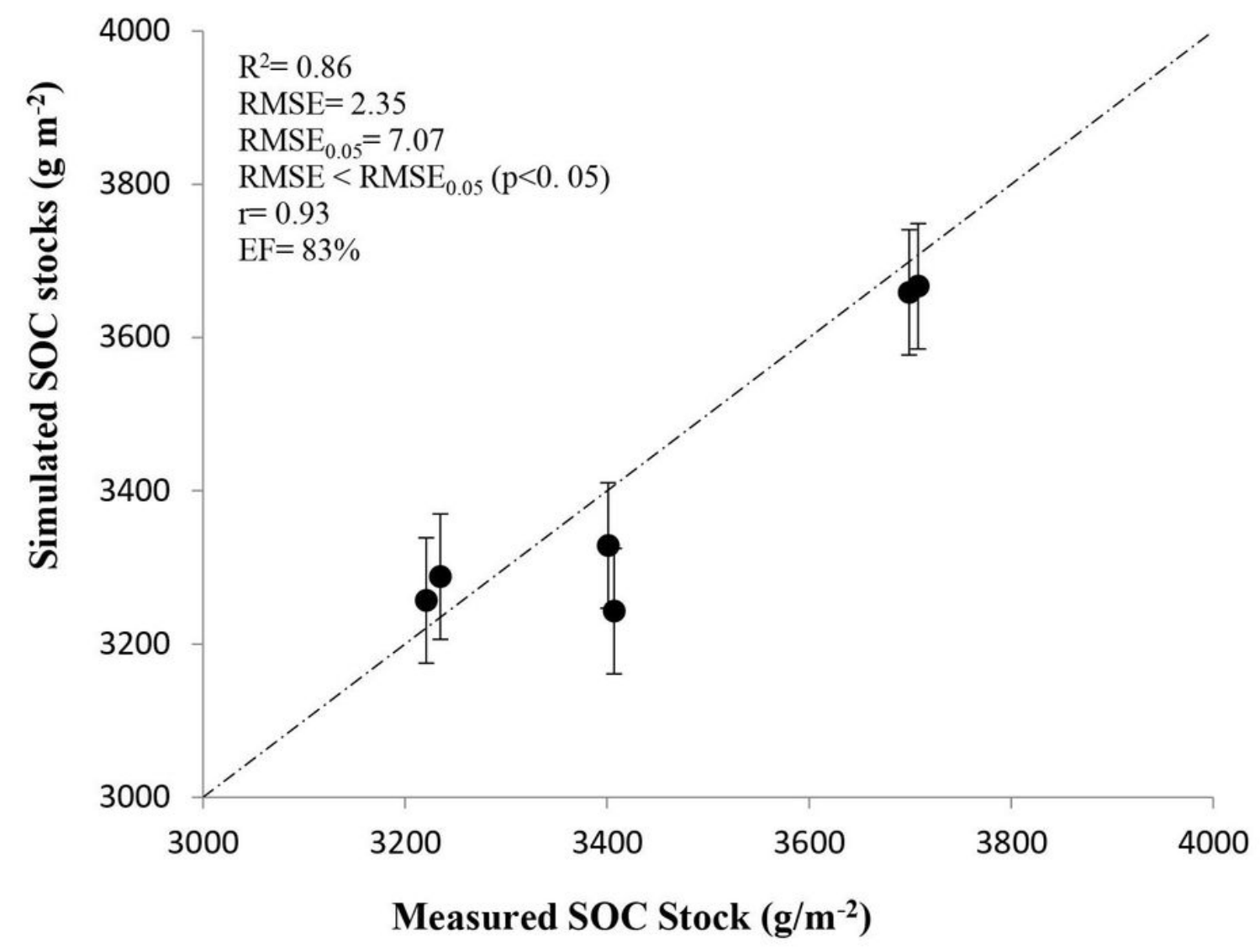

Figure 4

Measured and simulated SOC Stock in compared with 1:1 line. Vertical bars indicate the difference between measured and simulated values. EF compares simulations or predictions and observations on an average level, and ranges from -1 to 1 , with best performance at $E F=1$. 


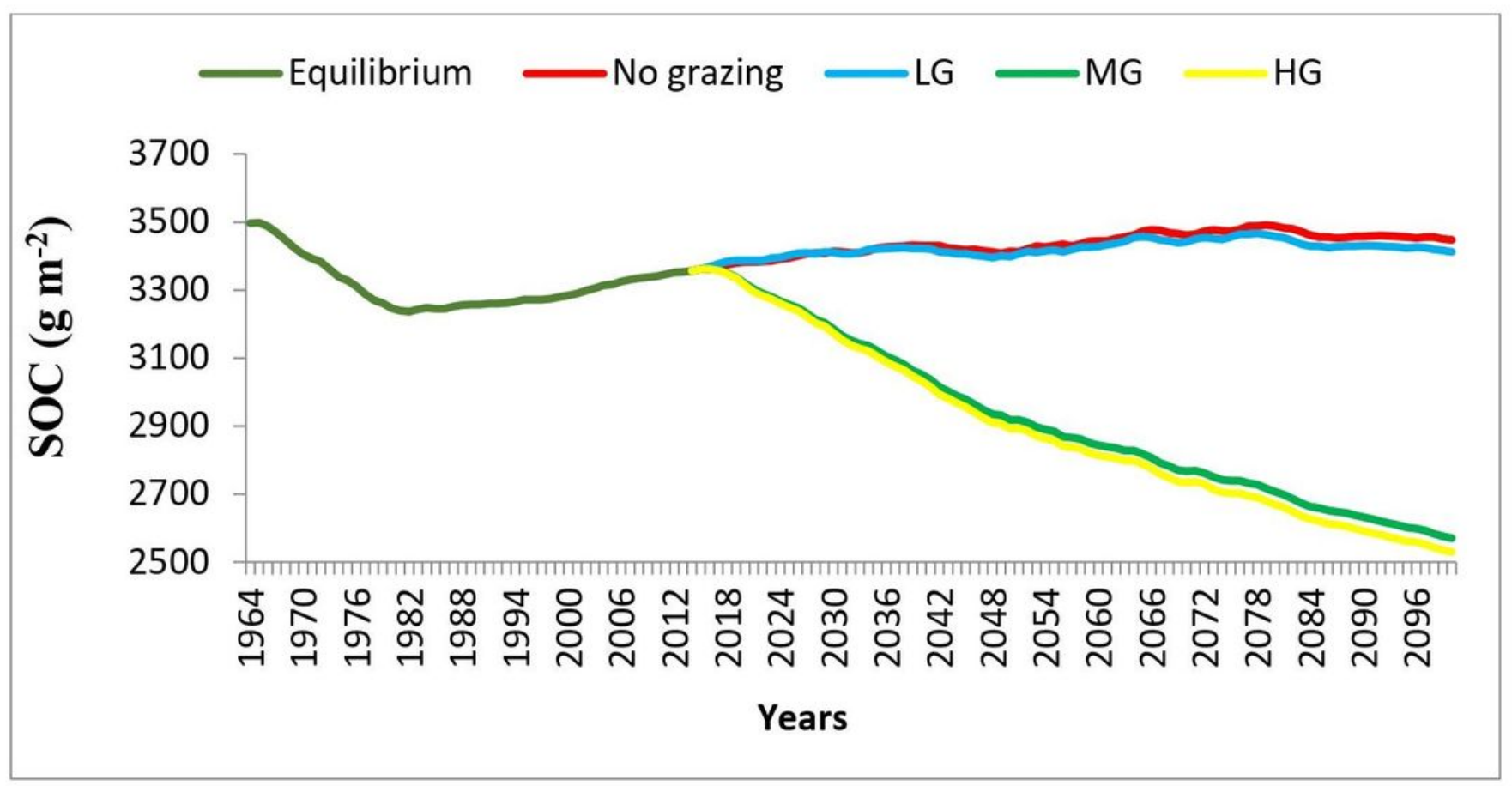

Figure 5

Simulated soil organic carbon (SOC) dynamics under different grazing intensity scenarios (No grazing, LG = Light Grazing, MG = Moderate Grazing, $H G$ =Heavy Grazing).

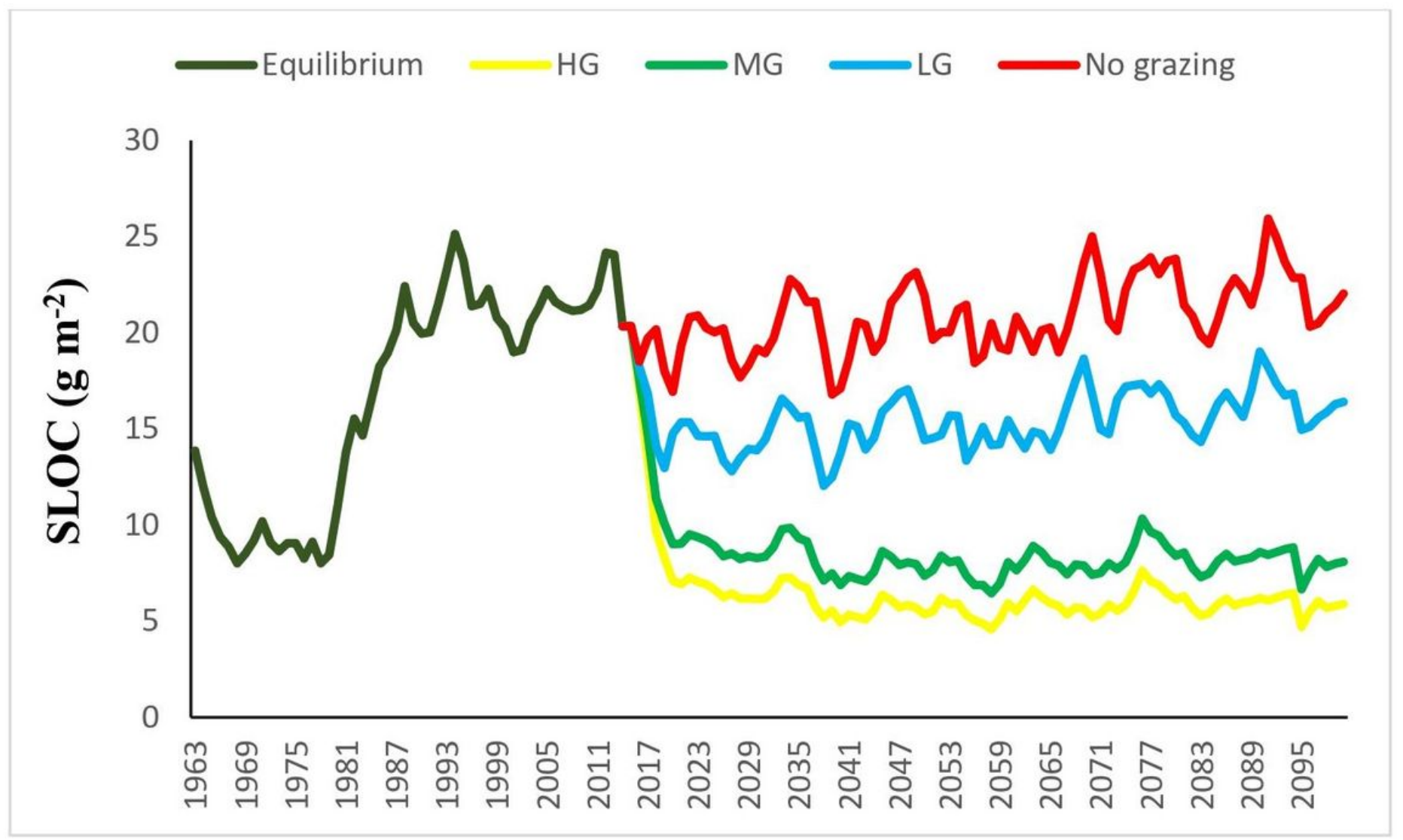


Figure 6

Simulated soil labile organic carbon (SLOC) dynamics under different grazing intensity scenarios (No grazing, $L G=$ Light Grazing, $M G=$ Moderate Grazing, $H G=$ Heavy Grazing). 